Familial Cold Autoinflammatory Syndrome
Published in final edited form as:
J Allergy Clin Immunol. 2001 October; 108(4): 615-620. doi:10.1067/mai.2001.118790.
Doctor Hal M Hoffman1
Doctor Hal M Hoffman: hahoffman@popmail.ucsd.edu
Division of Rheumatology, Allergy, and Immunology, University of California at San Diego, 9500
Gilman Drive, La Jolla, California 92093-0635, USA
Abstract
Familial cold autoinflammatory syndrome is an autosomal dominant inherited inflammatory
disease characterized by episodes of rash, fever, and joint pain following generalized exposure to
cold. Attacks usually occur 1-2 hours after exposure and last less than 24 hours. It has been
reported primarily in families from North America and Europe, but sporadic cases have also been
reported. The diagnosis is based on clinical presentation and can be confirmed by the
identification of a NALP3 mutation. No clinical trials have been performed with FCAS patients,
but anakinra, an IL-1 receptor antagonist, has been effective at preventing symptoms prior to a
cold challenge and as a maintenance medication in several patients. The NALP3 gene, also known
as CIAS1, is expressed in peripheral blood leukocytes and chondrocytes and codes a protein also
known as Cryopyrin. NALP3 mutations have also been identified in Muckle Wells syndrome and
Chronic infantile neurologic cutanaeous articular syndrome. There are several laboratories in
Europe and North America where sequencing of NALP3 is performed.

\title{
Keywords
}

familial cold urticaria; CIASI; cryopyrin; Pypaf1; NALP3; autosomal dominant transmission; inflammatory disorder

\section{Diagnostic criteria/Definition}

Diagnostic criteria have been proposed in order to distinguish FCAS from acquired cold urticaria and other periodic fever disorders.

Name of the disease and its synonyms

Familial Cold Autoinflammatory Syndrome (FCAS)

Familial Cold Urticaria (FCU)

Cold Hypersensitivity

Familial Polymorphous Cold Eruption

Excluded diseases

This list is not exhaustive

Acquired cold urticaria

Familial Mediterranean fever

Hyper IgD syndrome

TRAPS (TNF (tumor necrosis factor) Receptor-Associated Periodic Syndrome

FCAS, Muckle Wells syndrome (MWS), and chronic infantile neurologic cutaneous articular (CINCA) syndrome may represent phenotypes of a single disease as they are all caused by mutations of the same gene 
1. Recurrent intermittent episodes of fever and rash that primarily follow natural, experimental, or both types of generalized cold exposure

2.

3. Age of onset $<6$ months

4. Duration of most attacks less than 24 hours

5. Presence of conjunctivitis associated with attacks

6. Absence of deafness, periorbital edema, lymphadenopathy, and serositis

\section{Comments on the differential diagnosis}

Four of six criteria are strongly suggestive of FCAS. Conjunctivitis is not as common as initially reported and there are several sporadic cases due to de novo mutations.

FCAS primarily is clinical diagnosis, although it is now possible to confirm it in most patients by NALP3 (CIAS1) mutation screening.

The following diseases can be excluded for these reasons:

- $\quad$ Acquired cold urticaria rarely presents in infancy, and does not present with fever and arthralgia. The rash in acquired cold urticaria occurs immediately after direct contact with cold and responds to antihistamines.

- $\quad$ Familial Mediterranean fever has longer episodes, a different rash, arthritis, and abdominal pain

- $\quad$ Hyper IgD has longer episodes, a different rash, diarrhea, adenopathies and increased IgD levels.

- $\quad$ TRAPS (TNF (tumor necrosis factor) receptor-associated periodic syndrome) has longer episodes, a different rash, and periorbital edema

\section{Frequency}

FCAS is extremely rare occurring at a rate of less that 1:1,000,000. It has been reported primarily in North America and Europe.

\section{Clinical description}

Most patients present at birth or within the first few months of life with rash. Episodes last throughout life and most patients have a normal life expectancy.

Most patients have some rash on a daily basis. However, attacks usually occur following exposures to cold or decreases in temperature including air conditioning and cool damp conditions. The first symptom is rash occurring 1-2 hours after exposure, followed by lowgrade fever and arthralgia approximately 4-6 hours after exposure. Other symptoms include myalgia, conjunctivitis, sweating, drowsiness, headache, extreme thirst, and nausea. Most attacks last less than 24 hours. Renal disease from AA amyloidosis is rare occurring in less than $2 \%$ of patients. 
There are several patients with clinical overlap with Muckle Wells syndrome (MWS) prompting many investigators to conclude that FCAS, MWS, and chronic infantile neurologic cutaneous articular (CINCA) are merely different phenotypes of a single disease.

\section{Management}

Until recently, the mainstay of treatment was supportive with warming treatments and nonsteroidal anti-inflammatory drugs. High dose corticosteroids can be effective, but most patients prefer symptoms to the side effects of steroids. Other treatments that have been successful in some cases include anabolic steroids and gold. Recently, several FCAS patients have been treated successfully with anakinra (kineret), a recombinant IL-1 receptor antagonist approved for the treatment of rheumatoid arthritis. While this therapy has not been studied in clinical trials, it has been reported to block symptoms after cold challenge.

\section{Etiology}

FCAS is inherited in an autosomal dominant trait; however there are several reported sporadic cases due to de novo mutations. The NALP3 gene (also known as CIAS1 and Pypaf1), localized to chromosome 1q44, was identified and confirmed by several groups. However, there are cases with classic FCAS symptoms that do not possess mutations in NALP3 suggesting the involvement of additional genes. Additionally, NALP3 mutations have been identified in patients with MWS and CINCA. The NALP3 protein is expressed in peripheral blood leukocytes and chondrocytes. It contains a pyrin domain (PYD), similar to the protein pyrin associated with Familial Mediterranean fever (FMF), which is involved in the regulation of inflammation and apoptosis via homotypic protein-protein interaction. It also contains a nucleotide binding NACHT domain and several leucine rich repeats, which is similar to several other proteins recently described including Nod2, the protein associated with Crohn's disease and Blau syndrome. NALP3 appears to bind to the ASC protein, which activates caspase 1, and NFkB leading to downstream cytokine release (including IL-1) and inflammation. It has been proposed that pyrin competes with NALP3 for ASC. NALP3 has also been implicated in apoptosis pathways.

\section{Biological diagnostic methods}

Sequencing of $N A L P 3$ is available at several centers to confirm the diagnosis, but there are some patients without mutations.

Currently all mutations to date have been identified in exon 3 which codes for the NACHT domain. At least 9 mutations have been reported including V198M, R260W, G301D, L305P, A353V, L353P, A439V, R488K, E627G. Some of these mutations have been associated with Muckle Wells syndrome. (http://fmf.igh.cnrs.fr/infevers)

\section{Genetic counseling}

The risk for each child born to an affected parent is $50 \%$.

Monitoring of renal function is suggested. 


\section{Prenatal diagnosis}

It is not indicated.

\section{Unresolved questions and comments}

It is still not understood how NALP3 mutations (including the same mutations) can result in such different phenotypes of FCAS, MWS, and CINCA. There is also no explanation for patients without NALP3 mutations. It is also not clear how exposure to cold temperatures can elicit attacks. Clinical trials with anakinra have not been performed.

\section{References}

1. Aganna E, Hammond L, Hawkins PN, Aldea A, McKee SA, van Amstel HK, Mischung C, Kusuhara K, Saulsbury FT, Lachmann HJ, Bybee A, McDermott EM, La Regina M, Arostegui JI, Campistol JM, Worthington S, High KP, Molloy MG, Baker N, Bidwell JL, Castaner JL, Whiteford ML, Janssens-Korpola PL, Manna R, Powell RJ, Woo P, Solis P, Minden K, Frenkel J, Yague J, Mirakian RM, Hitman GA, McDermott MF. Heterogeneity among patients with tumor necrosis factor receptor-associated periodic syndrome phenotypes. Arthritis Rheum. 2003; 48:2632-2644. [PubMed: 13130484]

2. Bertin J, DiStefano PS. The PYRIN domain: a novel motif found in apoptosis and inflammation proteins. Cell Death Differ. 2000; 7:1273-1274. [PubMed: 11270363]

3. Dode C, Le Du N, Cuisset L, Letourneur F, Berthelot JM, Vaudour G, Meyrier A, Watts RA, Scott DG, Nicholls A, Granel B, Frances C, Garcier F, Edery P, Boulinguez S, Domergues JP, Delpech M, Grateau G. New Mutations of CIAS1 That Are Responsible for Muckle-Wells Syndrome and Familial Cold Urticaria: A Novel Mutation Underlies Both Syndromes. Am J Hum Genet. 2002; 70:1498-1506. [PubMed: 11992256]

4. Feldmann J, Prieur AM, Quartier P, Berquin P, Certain S, Cortis E, Teillac-Hamel D, Fischer A, de Saint Basile G. Chronic Infantile Neurological Cutaneous and Articular Syndrome Is Caused by Mutations in CIAS1, a Gene Highly Expressed in Polymorphonuclear Cells and Chondrocytes. Am J Hum Genet. 2002; 71:198-203. [PubMed: 12032915]

5. Hoffman HM, Mueller JL, Broide DH, Wanderer AA, Kolodner RD. Mutation of a new gene encoding a putative pyrin-like protein cause familial cold auto inflammatory syndrome and MuckleWells syndrome. Nat Genet. 2001a; 29:301-305. [PubMed: 11687797]

6. Hoffman HM, Wanderer AA, Broide DH. Familial cold auto inflammatory syndrome: Phenotype and genotype of an autosomal dominant periodic fever. J Allergy Clin Immunol. 2001b; 108:615620. [PubMed: 11590390]

7. Hoffman HM, Wright FA, Broide DH, Wanderer AA, Kolodner RD. Identification of a locus on chromosome 1q44 for familial cold urticaria. Am J Hum Genet. 2000; 66:1693-1698. [PubMed: 10741953]

8. Hugot JP, Chamaillard M, Zouali H, Lesage S, Cezard JP, Belaiche J, Almer S, Tysk C, O'Morain CA, Gassull M, Binder V, Finkel Y, Cortot A, Modigliani R, Laurent-Puig P, Gower-Rousseau C, Macry J, Colombel JF, Sahbatou M, Thomas G. Association of NOD2 leucine-rich repeat variants with susceptibility to Crohn's disease. Nature. 2001; 411:599-603. [PubMed: 11385576]

9. Inohara N, Nunez G. The NOD: a signaling module that regulates apoptosis and host defense against pathogens. Oncogene. 2001; 1(20):6473-6481. [PubMed: 11607846]

10. Johnstone RF, Dolen WK, Hoffman HM. A Large Kindred with Familial Cold Autoinflammatory Syndrome. Ann Allergy Asthma Immunol. 2003; 90:233-237. [PubMed: 12602672]

11. Kile RL, Rusk HA. A Case of cold urticaria with an unusual family history. JAMA. 1940; 114:1067-1068.

12. Manji GA, Wang L, Geddes BJ, Brown M, Merriam S, Al-Garawi A, Mak S, Lora JM, Briskin M, Jurman M, Cao J, DiStefano PS, Bertin J. PYPAF1: A PYRIN-containing Apaf1-like protein that assembles with ASC and regulates activation of NF-kB. J Biol Chem. 2002; 10:10. 
13. Martinon F, Hofmann K, Tschopp J. The pyrin domain: a possible member of the death domainfold family implicated in apoptosis and inflammation. 2001

14. Miceli-Richard C, Lesage S, Rybojad M, Prieur AM, Manouvrier-Hanu S, Hafner R, Chamaillard M, Zouali H, Thomas G, Hugot JP. CARD15 mutations in Blau syndrome. Nat Genet. 2001; 29:19-20. [PubMed: 11528384]

15. Ogura Y, Bonen DK, Inohara N, Nicolae DL, Chen FF, Ramos R, Britton H, Moran T, Karaliuskas R, Duerr RH, Achkar JP, Brant SR, Bayless TM, Kirschner BS, Hanauer SB, Nunez G, Cho JH. A frame shift mutation in NOD2 associated with susceptibility to Crohn's disease. Nature. 2001; 411:603-606. [PubMed: 11385577]

16. Pawlowski K, Pio F, Chu Z, Reed JC, Godzik A. PAAD - a new protein domain associated with apoptosis, cancer and autoimmune diseases. Sci U S A. 2001; 89:8794-8797.

17. Wang L, Manji GA, Grenier JM, Al-Garawi A, Merriam S, Lora JM, Geddes BJ, Briskin M, DiStefano PS, Bertin J. PYPAF7: A novel PYRIN-containing Apaf1-like protein that regulates activation of NF-kB and caspase-1-dependent cytokine processing. J Biol Chem. 2002; 17:17. 